\title{
PROFESSOR VOLODYMYR FAVRE: PUBLIC HEALTH PERSONALITY AND CITIZEN (ON THE 100TH ANNIVERSARY OF HIS DEATH)
}

DOI: 10.36740/WLek202005133

\author{
Ihor Yu. Robak, Volodymyr A. Alkov, Hanna L. Demochko, Oleksandr V. Chernukha \\ KHARKIV NATIONAL MEDICAL UNIVERSITY, KHARKIV, UKRAINE
}

\begin{abstract}
The aim of the research is to create a chronological outline of the life and work of V. Favre, highlighting the most important facts. His medical and social activity in practical health care is emphasized as well.

Materials and methods: The research is based on methodological approaches used for systematic analysis of the historical process and the medicine representative as an integral part of historical and medical knowledge. A biographical approach is the main approach used herein. Phenomenological and paradigmatic approaches provide the necessary scientific tools to recreate the atmosphere of the relevant time period, to reconstruct V. Favre's outlook, to summarize his views, to determine his impact on public health development.

Conclusions: V. Favre was a prominent organizer and a scientist, a talented teacher and a public figure. He based his activity on promoting science in the wider circles. The doctor firmly believed that the future belonged to prophylactic medicine. For his short life span V. Favre managed to do many things to deserve an uncreated monument in the history of the city and public health of the whole country.
\end{abstract}

KEY WORDS: public hygiene, sanitation, biography, the Russian Empire, Kharkiv

Wiad Lek. 2020;73(5):1016-1020

\section{INTRODUCTION}

Biographical researches seem to be one of the most popular in the history of public health. Usually they are interdisciplinary in nature, including local history, historical biographising, social history, special medical disciplines, and many more sciences to study the physician's personality. To comprehend the medicine genesis and focus, researchers study biographies of illustrious personalities achieved significant success in their professional activity and respected by their contemporaries in their lifetime, and after their decease joined those eminent physicians remembered with gratitude by descendants. This allows to contribute to the study of local medical history by personalizing it.

Among those people, Volodymyr Favre (1874-1920), an outstanding hygienist and malariologist of the Russian Empire and early Soviet era, undoubtedly deserves attention in commemoration of $100^{\text {th }}$ anniversary from his death in 1920 (Fig.1). His short biography represents a specific example of the public health evolution in the social, economic and political system in the country, and to focus directly on events in his hometown of Kharkiv, an important city in the Russian Empire and in the history of European medicine.

\section{THE AIM}

Therefore, the goal of the proposed research is to create a chronological outline of V. Favre's life and activities, highlighting the most important facts. Professional and com-

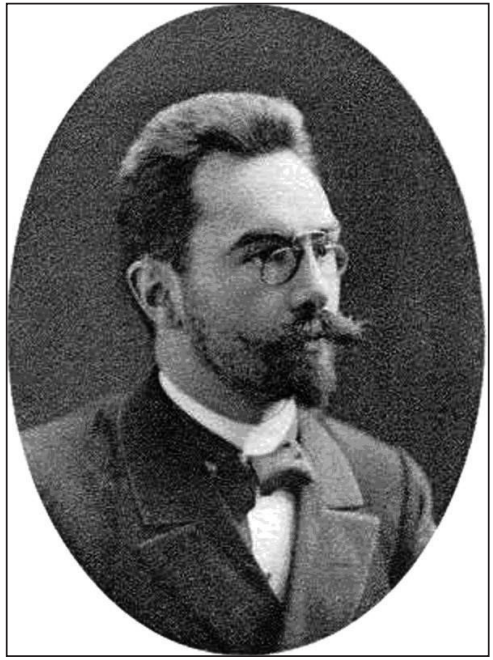

Fig.1. Volodymyr Favre (1874-1920).

munity work in practical health care are to be emphasized. However the scientific works are analyzed shallow enough, since a careful analysis would require a deepening into the special medical disciplines uncovered by our research.

\section{MATERIALS AND METHODS}

The research is based on methodological approaches used for systematic analysis of the historical process and the medicine representative as an integral part of historical and medical knowledge. A biographical approach to view historical reality in time and space widely embraces the 
issue in historical context. The biographical approach in the history of health care helps to find reasons for medical ideas and innovations in various biographical facts to appear, to reveal those patterns in empirical facts which played a crucial role in formation of the physician's outlook. Phenomenological and paradigmatic approaches provide the necessary scientific tools to recreate the atmosphere of the relevant time period, to reconstruct V. Favre's outlook, to summarize his views, to determine his impact on public health development. We also note the importance of compliance with the principle of historicism, the objectivity of reporting facts when using all sources of information and avoiding the idealization of the past, their dogmatic status, in particular, this applies to medicine representatives.

\section{REVIEW AND DISCUSSION}

Volodymyr Favre was born on July 05 (17), 1874 in Kharkiv into a family of a doctor of Swiss descent [1]. He studied at the $1^{\text {st }}$ Kharkiv high school, completed the course in 1892 with a silver medal and entered the Medical faculty of Imperial Kharkiv University, and upon graduation in 1897 was awarded with "doctor with honor" title. Being a student, he was willing to do scientific work in chemistry, bacteriology and hygiene. After the fourth year, during summer vacations, he worked with professor Flugge at the Institute of Hygiene in Breslau, listening to a lecture course and attending practical classes in bacteriology, studying methods of practical hygiene.

Upon his university course, V. Favre was elected assistant at the Hygiene Department, headed by I. Skvortsov. He held this position during 1897-1904. At the same time he worked as the vice-director of the Kharkiv Regional Obstetrical College and was mentioned by his wife's relative $\mathrm{V}$. Dzunkovsky in his memoirs to be a famous obstetrician in Kharkiv [2]. V. Favre was a delegate to the XII International Congress of Physicians in Moscow (1897). In 1901, the University sent him to the Plague Laboratory at the Institute of Experimental Medicine in St. Petersburg to study microbiology and plague. He was engaged in malaria researches, participated in expeditions to malaria outbreak areas. Favre belonged to the category of ascetic doctors who deliberately infected themselves with little-known diseases in order to investigate them. In 1902, he contaminated himself with malaria from a new species of mosquito to prove it to be a vector. Later this species of malarial mosquito was also found in other southern European countries. His life was saved only thanks to his self-denying disciples. The results of malaria researches were discussed in V. Favre's report and practical proposals at the VIII Pirogov Congress in Moscow in 1902. Following this statement, a special commission to combat malaria was established by the Pirogov Society, headed by renowned scientist G. Gabrychevsky [3].

Volodymyr Favre defended his doctoral thesis "Studying malaria in Russia in sanitary terms" in 1903, following by his admittance to the rank of Privatdozent of the Hygiene Department at the Imperial Kharkiv University in 1904. In 1903 and 1904 he studied malaria in the Caucasus, Voronezh and Kharkiv provinces. In 1904, together with G. Ostryanin, V. Favre headed the bacteriological unit, sent to the theater of military operations of the Russo-Japanese War. From 1906 to 1911 , he taught factory hygiene at the Kharkiv Institute of Technology. He wrote articles on hygiene for the fifth volume of the second half volume 'Medicine' of the People's Encyclopedia of Scientific and Applied Knowledge (Circle of Knowledge) (1910), published by the Kharkiv Literacy Society $[4 ; 5]$.

In 1911, he was elected Privatdozent of the Hygiene Department by the Women's Medical Institute board at the Kharkiv Medical Society and in 1916 he became Professor. In different years, he taught courses and gave lectures on hygiene and epidemiology at nursing courses at the Kharkiv nurse community at the Red Cross, at courses for workers, at the Veterinary Institute, and at teacher training courses. He went abroad for several times, where he learnt the organization of sanitary-epidemiological process. In 1910 , the plague commission sent him to Odessa to combat plague, where he joined the Regulatory Bureau and managed the plague measures until the end of the epidemic. In 1911, he was seconded to Primorsky and Amursky regions by the commission to prevent plague from entering Russia. He was a member of the Education Committee of Kharkiv Higher Commercial Courses (1915-1916), Associate Professor at the Hygiene Department since 1918 [6, 7].

The merits of V. Favre in health care of Kharkiv are hard to overestimate. From 1905, he headed the city sanitary department (sanitary bureau, or sanitary department of city government). The name of $\mathrm{V}$. Favre is associated with real breakthrough in development of the sanitary-epidemiological service and sanitary regulation in Kharkiv. At his time the number of municipal public health doctors increased from one to four and a sanitation bureau started functioning. At his initiative, a fifth outpatient clinic was established. Under his leadership, sanitary trusteeships were organized and the Museum of Factory Hygiene was opened. The Sanitary Committee at the Kharkiv Literacy Society, with the assistance of V. Favre, planned to equip schools with first aid kits, to introduce hygiene classes in senior classes, giving elementary knowledge of anatomy and physiology, and to provide medical supervision of students [7]. In order to study biological treatment facilities in cities, V. Favre was sent by the City Council to Europe (1907 and 1913). With European experience, Volodymyr began to integrate it into Kharkiv life. The city's sewage train and the indoor market at the Blagovishensky Bazaar should be considered his merit. On the other hand, he wrote many instructions for sanitary, medical, public health and other commissions of the City Council, the project of medical supervision in city schools, measures for organization of city public patronage and many other similar works [8].

V. Favre focused on prevention of infectious diseases in the city. He established close contact of the city sanitary service with hospitals, local outpatient clinics and the Institute of School Physicians. Effective measures were taken to expand and regulate overnight shelters, to organize canteens and public bathing facilities, to fight against drinking and prostitution. 
Concerning prostitution, V. Favre categorically insisted on its prohibition, believing that its regulation contradicted not only to moral standards, but also to sanitary requirements.

Standing for the closure of brothels as sexually transmitted infection breeders, V. Favre believed that municipal government should abandon prostitution control and focus on sanitation and awareness-raising activities aimed at preventing diseases [9].

V. Favre entered the Kharkiv Medical Society in the year of graduation from the University. In the next 1898, he made a detailed report "On Hungry Bread", which provoked wide discussions [10]. As a result, at the initiative of V. Favre, a committee of the Kharkiv Medical Society was created to assist the starving, which later became a powerful public organization.

The first report was followed by more others. Volodymyr Favre's reports always attracted a large audience. These were the so-called "big days" in the KhMS. Not only interesting but also urgent and exciting scientific views were discussed. Therefore, as a rule, the discussion of such issues resulted in establishment of special commissions for practical implementation of the decisions of the society. Thus, in different years commissions were established to assist the starving, to build a shelter for terminally ill patients named after Dr. V. Frankovsky, to fight plague, cholera, typhoid, trichinous diseases in Kharkiv, to organize a "flying bacteriological detachment" in the Far East, to open a chemical-pharmaceutical institute, to reorganize medical society institutions, etc.

V. Favre was one of the organizers of the sector of public medicine, hygiene and demography in the Kharkiv Medical Society in 1907. Elected chairman in 1909, he determined its tasks, which included assisting local authorities and city organizations in implementation of broad measures to improve sanitary conditions in Kharkiv. V. Favre read bacteriological courses in the Medical Society. In 1906-1912, he was an editor at the Hygiene Department and an executive secretary of "Kharkiv Medical Journal" [11]. Since "Medical Practice" journal foundation in 1918 and until his death, he was an executive editor and editor at the Department of Hygiene, Sanitation and Urban Medicine [12].

V. Favre created a great scientific work on issues of malaria, plague, cholera, typhoid fever, scarlet fever, sanitary treatment of pulmonary patients, sanitary and living conditions of townies and peasants, school sanitary supervision, dining arrangement in Kharkiv, ways of social and state struggle against people's alcoholism, study of sexual life of Kharkiv students and spread of sexually transmitted diseases in that environment, fight against infectious diseases in wartime and, finally, development of a sanitary epidemic activity in Kharkiv $[13 ; 14 ; 15 ; 16]$.

At the beginning of the $20^{\text {th }}$ century, when the health care organization started functioning in Kharkiv, its practical activity needed to be covered and explored. So the "Review of the Kharkiv City Medical and Sanitary Organization (1910-1914)" appeared [13]. V. Favre noted therein that the Kharkiv city medical and sanitary organization had already determined certain aspects at that time, he paid attention to quantitative dynamics of its growth, types and scope of medical aid, hospital case and sanitary service, problems of funding and material support, authorities' regulation of the city medical and sanitary activity, first achievements and obstacles in practical activity, etc. The above paper was intended to draw public attention to urban health problems. It is believed to be important as it contains discussion of urgent issues of urban health care of that period. It is also worth pointing out that the author had very diverse materials in the nature and content that increased the value of his research.

Organization of the sanitary service is considered to be very interesting, since the general condition of infectious diseases in Kharkiv seemed terrible, frequent epidemics took thousands of lives, so, according to V. Favre, these problems were urgent to be solved. However, social factors, resulted in inevitable spread of diseases, were ignored. In general, the above paper considered first of all the medical and scientific aspect of the case from a specific (medical) perspective.

Volodymyr Favre also wrote the chapter "Medical and Sanitary Organization" in the collection "Modern Economy of the City of Kharkiv (1910-1913)" [14]. Unlike "Review of the Kharkiv City Medical and Sanitary Organization" (1910-1914), the collection contained description of the issues of fighting against infectious diseases in the city in more detail. Besides, the collection contained information on sanitary cleaning of the city, the water supply, activities of city authorities in food hygiene (control of infectious diseases of livestock, supervision of dairy farms and dairy products selling, supervision of slaughterhouses, meat processing enterprises and meat shops).

In general, Favre's papers outlined a number of issues required further clarification. First of all, questions about the causes of the most common diseases and epidemics in Kharkiv and ways of combating them, the evolution of the health care management in the city, improving the medical assistance to the population (inpatient, outpatient, provision of new medicines) and its new types (ambulance and first aid). His works collected studied data, seemed to be very interesting, he used sources, unavailable now. So, in terms of factual account, these works are believed to be undoubtedly valuable and rich in content.

The figure of V. Favre was known in Kharkiv not only as a city official, a scientist and a teacher. V. Favre believed that "hygiene is a natural defender of the suffering, the poor, the weak, the oppressed, and the sick to bring them out of hell of disasters, mitigating the hardest situations and intervening wherever a person may face the disease: in factories, in a carriage and even in prison" [12]. Therefore, a prominent specialist in social hygiene V. Favre could not stay away from the social problems explored in this science. Thus he actively spoke not only at a professional but also public level. V. Favre characterized his ideal as a medical scientist able to successfully combine professional and social and educational activities [7].

V. Favre and the university professors M. Gredeskul, D. Bahaliy, M. Sumtsov were leaders of the Kharkiv branch 
of the Constitutional Democratic Party. Party of constitutional democrats was the most influential in Kharkiv, as seen from the elections to the State Duma of the Russian Empire. Favre was a democrat, but supported evolution, not revolution. He supported Ukrainophilia, decisively rejecting any manifestations of great-power chauvinism. In the Jewish issue, Volodymyr proved himself a consistent opponent of anti-Semitism. So, having the authority in medical and political circles, V. Favre was sent by the Kharkiv Medical Society to St. Petersburg in 1913 to ask to abolish the decision on closure of the KhMS for its anti-government resolution on the notorious "Baylis case." This mission was successful. And then V. Favre actively opposed Anti-Jewish pogroms.

During the First World War, he worked at the Kharkiv Regional Committee of the All-Russian Union of Cities (since 1914), from its foundation, and headed the sanitary-engineering bureau there in 1916-1917. At the initiative and plan of V. Favre, hospital No. 13 of the Union of Cities, served as an infectious veil, was built in Kharkiv. In 1915 he studied sanitary measures and sanitary facilities of the Union of Cities and the Zemsky Union on the Southwest Front.

V. Favre accepted the February revolution unconditionally. He wrote: "The insolvency of the previous regime and the need to move to a more free system, so that citizens have the right to self-determination and the opportunity to organize without usual restrictions, allow to expect citizens' interest in organization, union and self-help in different spheres of urban life, in particular, political, education, sanitary" [9]. The Provisional Government invited V. Favre to Petrograd to develop a project for the reorganization of the medical and sanitary field.

The spread of the October revolution, the Bolsheviks' violence depressingly affected the scientist and made him to cooperate with the Denikin's Army. In 1919, while the Denikin's Army was in Kharkiv, Volodymyr headed the city sanitary service and was a member of the C-D party of the City Council. For this, later the Bolsheviks tried to hold him accountable, but changed their minds, because the professor actively cooperated with the Soviet authorities in establishing a new health care system. Moreover, he was later mentioned in Soviet encyclopedias. During the epidemic of typhus, Volodymyr Favre worked in the emergency commission to combat the epidemic, and infected this terrible disease and died in his prime on March 24, 1920 [17; 18].

Despite many years of his fruitful work, the life of V. Favre has been researched fragmentarily, so the scientist's diverse activity should be comprehensively studied. The researches devoted to him are mostly related to certain events (the death of the scientist; his anniversary dates or anniversaries of the institutions where he worked) [12;9; $6 ; 3 ; 4]$. Some materials are contained in works on local medical history in Kharkiv [8] and in many general works on the history of malaria. However, they just mentioned touched the physician, except for a paper by T. Lutayeva, who studied his scientific-pedagogical and public-educational activities [7].

\section{CONCLUSIONS}

The brief biographical information indicates the vigorous versatile activity of V. Favre and his intensive work. Historical facts convincingly prove that he was extremely gifted and competent, energetic and hardworking. His great authority in Kharkiv was associated with his highly productive work in various fields - scientific activity in social medicine, teaching, literary, public, and above all, administrative and organizational activity. As a talented, tireless, versatile scientist, he always had a great influence on Kharkiv public self-government. The greatest reforms and innovations in the urban economy emerged either at his initiative or with his participation and under his supervision as a specialist-practitioner. From February 1905 until November 1919, Volodymyr served as an organizer, consultant and often executor of works related to Kharkiv medical and sanitary life. Without exaggeration, we can consider him the founder of the modern city sanitary and epidemiological service in Kharkiv.

As a scientist and teacher, V. Favre based his activity on getting science closer to people and promoting it in the wider circles. He firmly believed (and time proved him right) that the future belonged to preventive, prophylactic medicine. Kharkiv owes him for education of many medical doctors, his followers in medical science application to the sanitary practice, desiring for scientific and practical improvement.

Therefore, Kharkiv gave credit to Volodymyr Favre, a prominent organizer, an outstanding scientist, a talented teacher and a public figure for all he did for his short life span, put an uncreated monument in the history of the city and public health of the whole country.

\section{REFERENCES}

1. Zhuravlev V. A. Vrachebnyy podvig otechestvennykh uchenykh (odna iz tragicheskikh stranits istorii nashey nauki) [The Medical Feat of Domestic Scientists (One out of Tragic Pages in History of Our Science)]. International Medical Journal. 2018; 24(3): 79-84. (RU)

2. Dzhunkovskiy V. F. Vospominaniya [Memoirs]. Vol. 1. Moscow: Sabashnikovs Press; 1997. (RU)

3. Dukhanina N. N., Dzhavadov R. B. K 100-letiyu so dnya rozhdeniya V. V. Favra (1874-1974) [On the Centenary of the Birth of V. V. Favre (1874-1974)]. Medical Parasitology and Parasitic Diseases. 1975; 44(2): 211-212. (RU)

4. Istoriya Kharkivs'kogo derzhavnogo medichnogo universitetu [History of Kharkiv State Medical University]. Kharkiv: Contrast; 2005. (UA)

5. Narodnaja Jenciklopedija nauchnyh i prikladnyh znanij. Har'kovskoe obshhestvo rasprostranenija v narode gramotnosti [People's Encyclopedia of Scientific and Applied Knowledge]. Vol. 5. Medicine. Part 2. Moscow : Sytin Partnership; 1910. (RU)

6. Vcheni universitetu. Khark. derzh. med. un-t [Scientists of the University. Khakiv State Medical University]. Kharkiv : KhSMU; 2002. (UA)

7. Lutaeva T. V. Naukovo-pedagogichna ta gromads'ko-prosvitnyc'ka dijal'nist'Volodymyra Favra [Scientific, Pedagogical, Public and Political Activities of Volodymyr Favre]. Herald of Postgraduate Education. 2016; 2(31): 73-86. (UA)

8. Robakı.Yu. Organizacija ohorony zdorov'ja v Harkovi za impers'koi'doby (pochatok XVIII st. - 1916 r.) [Organization of Health Care in Kharkiv during the Emperial era (Early 18th Century - 1916)]. Kharkiv: KhSMU; 2007. (UA) 
9. Vladimir Vladimirovich Favr, ego zhizn' i deyatel'nost' [Volodymyr Volodymyrovych Favre, His Life and Activities]. Kharkiv : Our Thought; 1920. (RU)

10. Favre V. V. 0 golodnom hlebe 1898 goda [On Hungry Bread of 1898]. Proceedings of Kharkiv Medical Society. Kharkiv: [n. p.]; [n.y.]:1-26. (RU)

11. Har'kovskoe medicinskoe obshhestvo (1861-1911): ocherki ego pjatidesjatilet. dejatel'nosti [Kharkiv Medical Society (1861-1911): Essays on Fifty Years of Its Activity]. Kharkiv: M. Zilberberg \& Sons; 1913. (RU)

12. Vladimir Vladimirovich Favr [Volodymyr Volodymyrovych Favre]. Medical Business. 1920; 9-10: 273-282. (RU)

13. Favre V. Obzor Har'kovskoj gorodskoj lechebno-sanitarnoj organizacii (1910-1914 gg.) [Review of the Kharkiv City Medical and Sanitary Organization (1910-1914)]. Kharkiv : Education; [n. y.]. (RU)

14. Sovremennoe hozjajstvo goroda Har'kova (1910-1913) [Modern Economy of the City of Kharkiv (1910-1913)]. Issue 1. Kharkiv : Education; 1914; Issue. 2. Kharkiv : Education; 1914. (RU)

15. Favre V.V. Ocherki gorodskoj sanitarii [Essays on City Sanitation]. Kharkiv Medical Journal. 1906; 1(5): 466-472. (RU)

16. Favre V. V. Sluchai holery v Har'kove osen'ju $1907 \mathrm{~g}$. [Cases of Cholera in Kharkiv in the Autumn of 1907]. Kharkiv Medical Journal. 1907; 4(9): 431-434. (RU)

17. Favr Vladimir Vladimirovich [Favre Volodymyr Volodymyrovych]. In: Big Medical Encyclopedia. Moscow; 1985. Vol. 26: 167. (RU)

18. Favr Vladimir Vladimirovich [Favre Volodymyr Volodymyrovych]. In: Ukrainian Soviet Encyclopedia. Kyiv; 1984. Vol. 11, book 1: 446. (RU)
The article was prepared in frames of the theme with a state registration No. 0118 U000933 "Medical Local Studies of Kharkiv in Personalities".

\section{ORCID and contributionship:}

Ihor Yu. Robak - 0000-0002-4837-4058 ${ }^{A, B}$

Volodymyr A. Alkov - 0000-0002-5339-7828 ${ }^{D}$

Hanna L. Demochko - 0000-0001-5744-5893 ${ }^{E}$

Oleksandr V. Chernukha - 0000-0003-2151-2067 ${ }^{F}$

\section{Conflict of interest:}

The Authors declare no conflict of interest

\section{CORRESPONDING AUTHOR Volodymyr A. Alkov}

Kharkiv National Medical University

Nayky Ave, 4, Kharkiv, Ukraine

tel: +380935690444

e-mail: vlalkov@rambler.ru

Received: 28.01.2020

Accepted: 02.04 .2020

A - Work concept and design, B - Data collection and analysis, C - Responsibility for statistical analysis,

D-Writing the article, $\mathbf{E}$-Critical review, $\mathbf{F}$ - Final approval of the article 